\title{
DETENTION OF REFUGEES IN NEW ZEALAND LAW: STRIKING A BALANCE BETWEEN REFUGEE RIGHTS AND NATIONAL SECURITY
}

\author{
Charlotte Frater
}

In this paper the author examines New Zealand's international obligations regarding the detention of Refugees and how these are implemented domestically. Article 31 of the Refugee Convention 1951 states that their detention is only permissible where necessary, and related documents outline these circumstances. The Convention contains an appropriate balance between the special needs of refugees and respect for national security, which unfortunately is not always present in our domestic legislation.

Section 128(5) of the Immigration Act 1987 allows refugees to be detained. However, this is subject to the requirements of the Convention due to section 129X(2) of the Act. The Court of Appeal in the Refugee Council case ${ }^{1}$ decided that an operational instruction issued after September 11, and coinciding with a significant increase in the numbers detained, was not unlawful. The author argues that the balance has swung too far in favour of national security, but concedes that the Immigration Amendment Act 2002 has gone some way to rectify the situation by providing conditional release procedures.

\section{INTRODUCTION}

New Zealand, as a sovereign state, has the right to control its borders. One of the most effective ways of exercising this control is to detain those whom the state does not want to enter. This not only prevents unwanted persons from entering the community, but also deters other undesirables from trying to do so.

* Paper submitted in partial completion of the LLB(Hons) degree at Victoria University of Wellington.

1 Attorney-General v Refugee Council of New Zealand [2003] 2 NZLR 572. 
However, New Zealand has voluntarily limited this right to control its border by acceding to the 1951 Convention Relating to the Status of Refugees ("The Convention") $)^{2}$ and the 1967 Protocol ("the Protocol:), ${ }^{3}$ which require that certain rights be afforded to refugee status claimants that other illegal aliens do not enjoy. This special treatment is in recognition of the difficult circumstances refugees face.

Events of the past few years highlight the conflicts that can arise between these different interests, and the impact this has on the way refugees are dealt with. On the one hand the terrorist attacks of September 11, and the concerns about people smuggling which were raised by the Tampa affair, focussed attention on the importance of national security. On the other, the widespread condemnation of the actions of the Australian Government in relation to refugees generally, reinforced the need for acceptable standards of treatment.

Thus, the State needs to accommodate the rights of refugee status claimants under the Convention with the right of the Crown to defend its borders. The question is whether New Zealand has found the appropriate balance.

In New Zealand, the statutory authority for the detention of illegal immigrants is found in section 128(5) of the Immigration Act 1987. Two recent developments have modified the position regarding detention of refugee status claimants under this section. The first is the Court of Appeal judgment in Refugee Council of New Zealand and the Human Rights Foundation of Aotearoa New Zealand and D v Attorney-General, ${ }^{4}$ which interpreted section 128(5), and in particular whether it can apply to refugee status claimants. The second is the Immigration Amendment Act 2002, which inserted a new section 128AA providing for conditional release of those detained under section 128(5). In this article I will discuss both of these developments in the light of New Zealand's international obligations. Have we achieved the correct balance between national security and liberty of the person? Are we any closer to it?

2 Convention relating to the Status of Refugees (28 July 1951) 189 UNTS 137 (the Convention); NZ acceded 30 June 1960: 363 UNTS 404.

3 Protocol relating to the Status of Refugees (31 January 1967) 606 UNTS 267 (the Protocol); NZ acceded 6 August 1973: 884 UNTS 108.

4 Refugee Council case (Court of Appeal), above. 


\section{INTERNATIONAL OBLIGATIONS}

\section{A The 1951 Refugee Convention and the 1967 Protocol}

\section{Introduction}

The Convention Relating to the Status of Refugees 5 is the principal source of refugee rights. ${ }^{6}$ It was adopted by the United Nations General Assembly on 28 July 1951, and came into force in April 1954. Essentially the Convention lays down minimum standards for the treatment of refugees.

Initially, the Convention was limited in its application to people who became refugees as a result of events before 1 January 1951. Refugees were considered a temporary problem resulting from World War II, which would in time go away. But instead the problem grew. It became necessary to enact the 1967 Protocol Relating to the Status of Refugees to remove the geographical and temporal limits from the 1951 Convention.

Fifty-one years after its creation, the United Nations Commissioner for Refugees (UNHCR) ${ }^{7}$ still has plenty to do, and the Refugee Convention it promotes is as relevant today as it was then. ${ }^{8}$

5 Convention relating to the Status of Refugees (28 July 1951) 189 UNTS 137

6 This paper is primarily concerned with protection from detention under the Refugee Convention. However, it is important to note that besides the Convention, several other international documents give rise to obligations to refugee status claimants, and, arguably give broader protection, by including those outside the restrictive Convention definition of "refugee". (See James C Hathaway The Law of Refugee Status (Butterworths, Toronto, 1991) 24-25). For example, Article 14 of the Universal Declaration of Human Rights protects the right "... to seek and to enjoy in other countries asylum from persecution". This is not a right to receive asylum, only to seek and enjoy it. However, when asylum seekers are not given adequate opportunity to present their case, or if once accepted as a refugee, excessive restraints or unreasonable conditions of detention are imposed, this may violate Article 14. (Richard Plender and Nuala Mole "Beyond the Geneva Convention: Constructing a De Facto Right of Asylum from International Human Rights Instruments" in Frances Nicholson and Patrick Twomey (eds) Refugee Rights and Realities: Evolving International Concepts and Regimes (Cambridge University Press, Cambridge, 1999) 81, 81-82).

Article $9(1)$ of the International Covenant on Civil and Political Rights (ICCPR) more explicitly concerns detention. It states that:

[e]veryone has the right to liberty and security of person. No one shall be subject to arbitrary arrest or detention. No one shall be deprived of his liberty except on such grounds and in accordance with such procedure as are established by law.

This gives an enforceable right to compensation where a person has been unlawfully arrested or detained.

Domestically, there may also be remedies in the New Zealand Bill of Rights Act 1990, particularly ss 21 (unreasonable search and seizure) and 22 (arbitrary detention).

7 The UNHCR was established on 14 December 1950 by the United Nations General Assembly. It seeks to protect refugees and help them restart their lives in a normal environment, but also works with groups such as internally displaced peoples who do not fit within the definition of "refugee". An important part of the agency's work involves international protection, promoting human rights agreements and monitoring 


\section{Definition of "refugee"}

The Convention recognises two types of refugees: quota refugees and spontaneous refugees. This paper deals only with spontaneous refugees who make their claim for refugee status on arrival at the New Zealand border, or after entry into New Zealand. ${ }^{9}$

Article $1 \mathrm{~A}(2)$ of the Convention defines the term "refugee". It applies to any person who:

owing to a well-founded fear of being persecuted for reasons of race, religion, nationality, membership of a particular social group or political opinion, is outside the country of his nationality and is unable or, owing to such fear, is unwilling to avail himself of the protection of that country; or who, not having a nationality and being outside the country of his former habitual residence as a result of such events, is unable or, owing to such fear, is unwilling to return to it.

Claimants must: (a) prove they are outside their country of origin; (b) establish that they are unable or unwilling to avail themselves of the protection of their country of origin; (c) establish that they are unable or unwilling to do so due to a well-founded fear of persecution; and (d) establish that the persecution is on the basis of criteria outlined in Article 1A(2) - race, religion, nationality, membership of a particular social group, or political opinion. ${ }^{10}$

The Convention definition of "refugee" is thus much narrower than the ordinary meaning of the word and does not include those fleeing natural disasters, or economic migrants. These people cannot benefit from the Convention, regardless of their need for assistance, because their situation is not due to a well-founded fear of persecution.

"Persecution" is not defined in the Convention but has been generally defined in New Zealand as " ... the sustained or systemic violation of basic human rights demonstrative of a failure of state

governmental compliance. Its efforts are mandated by its statute and guided by the 1951 Refugee Convention and the 1967 Protocol. See UNHCR <http://www.unhcr.ch/cgi-bin/texis/vtx/basics/> (last accessed 11 June 2003).

8 For example, as recently as 2002, the Ukraine acceded to the 1951 Convention and the 1967 Protocol. It joins over 140 state parties in doing so. See UNHCR $<$ http://www.unhcr.ch/cgi-bin/texis/vtx/home/ $>$ (last accessed 24 June 2003).

9 By contrast, quota refugees are selected, while still overseas, by the New Zealand government from countries predetermined by UNHCR for resettlement in New Zealand. For the most part these refugees are part of a mass movement provoked by invasion or oppression. New Zealand currently accepts $750 \mathrm{UN}$ quota refugees each year. (Rodger Haines "International Law and Refugees in New Zealand" [1999] NZ Law Rev 119, 123).

10 For a comprehensive examination of these requirements see James C Hathaway The Law of Refugee Status (Butterworths, Toronto, 1991). 
protection". ${ }^{11}$ Any well-founded fear will require examination of the class of persons affected, the interests in respect of which they stand to be punished, the likelihood of punishment, and the nature and extent of the penalties. ${ }^{12}$ Past persecution is not enough, there must be a well-founded fear of future persecution. ${ }^{13}$ For example, New Zealand is unlikely to get any more Iraqi refugees now that Saddam Hussein's regime has ended because the reason for their persecution no longer exists. ${ }^{14}$ Similarly, if the persecution is not claimed for a Convention reason, the claimant is not a refugee.

The Convention also contains a number of exception provisions. These state that the Convention does not cover people to whom Articles $1 \mathrm{C}$ to $1 \mathrm{~F}$ apply, even if they would otherwise qualify as refugees under Article 1A. This includes people who have ceased to require protection, receive protection from other United Nations agencies, have been given rights similar to nationals in their country of refuge and those who have committed certain crimes making them unworthy for protection.

\section{Protection of refugees}

Despite the fact that comparatively few claimants are eventually accepted as genuine refugees, all claimants must receive the benefit of certain Convention provisions while their claim is being determined. ${ }^{15}$ The definition is a declaratory statement. Refugee status exists as soon as the criteria in Article 1A are met, and independently of recognition by State parties. As the UNHCR states, a refugee "... does not become a refugee because of recognition, but is recognised because he is a refugee". ${ }^{16}$ Unless status assessment is virtually immediate, the only acceptable solution is for State parties to treat refugee status claimants as genuine refugees and afford them their Convention

11 This definition comes from Hathaway, above, 104 and was adopted by the Refugee Status Appeals Authority in Refugee Appeal No 1039/93 Re HBS and LBY (13 February 1995) 19 - 20. See also Refugee Appeal 71427/99 [2000] NZAR 545 at para 51.

12 Guy S Goodwin-Gill The Refugee in International Law (2 ed, Clarendon Press, Oxford, 1996) 77.

13 DG v Refugee Status Appeals Authority (5 June 2001) High Court Wellington CP213/00. See Rodger Haines "Immigration and Refugee Law: Update 2001- 2002" (Auckland District Law Society Seminar, 25 November 2002) for a good discussion of this case and the term "persecution' in New Zealand.

14 Haydon Dewes "Iraqi refugees may be the last" (26 April 2003) The Dominion Post Wellington 2.

15 The statistics relating to refugee status claimant applications demonstrate that the Convention definition of "refugee" is not an easy test to satisfy. In the year $2000-2001$, only 13.2 per cent of the 2350 refugee status applications decided by the Refugee Status Branch in New Zealand were accepted, with 86.8 per cent declined. (Statistics found at $<$ http://www.refugee.org.nz/stats/htm> (last accessed 10 June 2003)).

16 UNHCR Handbook on Procedures and Criteria for Determining Refugee Status under the 1951 Convention and the 1967 Protocol relating to the Status of Refugees (UNHCR, Geneva, 1979) para 28. 
rights. ${ }^{17}$ However, there is reason to suggest that where a refugee status claim is clearly not bona fide, such rights do not apply. ${ }^{18}$

Article 31 of the Convention protects spontaneous refugees from arbitrary detention. It states: ${ }^{19}$

1. The Contracting States shall not impose penalties, on account of their illegal entry or presence, on refugees who, coming directly from a territory where their life or freedom was threatened in the sense of Article 1, enter or are present in their territory without authorisation, provided they present themselves without delay to the authorities and show good cause for their illegal entry or presence.

2. The Contracting States shall not apply to the movements of such refugees restrictions other than those which are necessary and such restrictions shall only be applied until their status in the country is regularised or they obtain admission into another country. The Contracting States shall allow such refugees a reasonable period and all the necessary facilities to obtain admission into another country.

It has been argued that the words "such refugees" in Article 31.2 refer back to Article 31.1, whose requirements must also be satisfied in order to claim protection under Article $31.2,{ }^{20}$ for example, the requirement that they have come directly from a territory where their life was threatened. Such an interpretation would severely limit the scope of Article 31.2. While it can be supported by the UNHCR Guidelines, ${ }^{21}$ there is no support in the travaux preparatoires for this approach. This has led some commentators to argue that "such refugees" simply means people who enter or are present in a territory unlawfully and who claim refugee status. ${ }^{22}$

17 Rodger Haines "International Law and Refugees in New Zealand" [1999] NZ Law Rev 119, 129 citing James C Hathaway and R Alexander Neve in "Making International Refugee Law Relevant Again: A Proposal for Collectivized and Solution-Orientated Protection" (1997) 10 Harv HR J 115, 158.

18 Atle Grahl Madsen Commentary on the Refugee Convention 1951 (Division of International Protection of the United Nations High Commissioner for Refugees, Geneva, 1997) 180.

19 Convention Relating to the Status of Refugees (28 July 1951) 189 UNTS 137, art 31 (emphasis added).

20 Asher Davidson Article 31(2) of the Refugee Convention and its Implementation in New Zealand: Is Detention Defensible? (LLB(Hons) Dissertation, University of Auckland, 2000) para 21 -28.

21 UNHCR UNHCR Revised Guidelines on Applicable Criteria and Standards Relating to the Detention of Asylum Seekers(UNHCR, Geneva, 1999) Introduction, para 2.

22 Atle Grahl-Madsen Commentary on the Refugee Convention 1951 (Division of International Protection of the United Nations High Commissioner for Refugees, Geneva, 1997) 179-180. 
In New Zealand there has been no authoritative comment yet as to which interpretation is preferred. $^{23}$ In either case, Article 31.2 requires greater justification for detention of refugees than other illegal aliens.

(a) Detention

"Detention" has been defined by the UNHCR Revised Guidelines on Applicable Criteria and Standards Relating to the Detention of Asylum Seekers ${ }^{24}$ (the Guidelines) as: ${ }^{25}$

... confinement within a narrowly bounded or restricted location, including prisons, closed camps, detention facilities or airport transit zones, where freedom of movement is substantially curtailed, and where the only opportunity to leave this limited area is to leave the territory.

In its framework paper on the detention of asylum seekers and refugees, the UNHCR makes it clear that their detention "raises significant concern", and is to be avoided. ${ }^{26}$ Most asylum seekers have not committed crimes, nor are they suspected of having done so. Furthermore, because refugees and asylum seekers are fleeing persecution they may be unable to enter a country legally. ${ }^{27}$ The fact that someone has entered a contracting state's territory illegally does not prevent them fulfilling the Convention definition of refugee, or enjoying the consequent benefits. The Conference of Plenipotentiaries expressly rejected the submission that fraudulent entrants be excluded from protection, as Article 31 demonstrates. ${ }^{28}$

23 See Abu v Superintendent of Mount Eden Women's Prison [2000] NZAR 260 para 15 (HC) where the Crown argued that the former, more restrictive, approach applied. However, this approach was neither adopted nor dismissed by the Court. In the Refugee Council Case the Crown also tried to argue for a different detention test depending on whether the claimant came directly. The Operational Instruction in issue did not deal with this question, and the Court of Appeal found it unnecessary to consider it. See Glazebrook J, para 291.

24 Note that although the guidelines may be relevant for interpretation purposes - particularly for judges exercising their discretion under ss 128 and 128A, they do not have the same status as the Conclusions of the Executive Committee of the UNHCR and do not impose obligations on the Minister in considering applications for temporary permits by refugee status claimants: See Attorney-General v E [2000] 3 NZLR 257 para 39 (CA) (majority) and Attorney-General v Refugee Council of New Zealand [2003] 2 NZLR 572, para 111.

25 UNHCR UNHCR Revised Guidelines on Applicable Criteria and Standards Relating to the Detention of Asylum Seekers (February 1999) Guideline 1.

26 Executive Committee of the High Commissioner's Programme Standing Committee "Detention of AsylumSeekers and Refugees: the Framework, the Problem and Recommended Practice" (Standing Committee $15^{\text {th }}$ meeting, Geneva, 4 June 1999) para 1.

27 Executive Committee of the High Commissioner's Programme Standing Committee "Detention of AsylumSeekers and Refugees: the Framework, the Problem and Recommended Practice" (Standing Committee $15^{\text {th }}$ meeting, Geneva, 4 June 1999) para 1.

28 James C Hathaway The Law of Refugee Status (Butterworths, Toronto, 1991) 50-51. 
Arbitrary detention is a human rights violation, and can be a form of persecution. ${ }^{29}$ Detention is arbitrary when it is not in accordance with the law, or the law allows for arbitrary practices, or the law is enforced in an arbitrary way. ${ }^{30}$ This can include random, capricious, and disproportionate practices of detention, or where its duration is indefinite or there is no fair and efficient review procedure available. ${ }^{31}$

(b) "Necessary" restrictions under Article 31.2

The Executive Committee statement in Conclusion No 44 (XXXVII) - 1986 Detention of Refugees and Asylum Seekers ${ }^{32}$ defines when detention may be necessary under Article 31:33 grounds for detention must be prescribed by law. They are limited to verifying identity, determining the elements on which the claim to refugee status is based, dealing with cases where refugees have destroyed their travel or identity documents, or have used fraudulent documents in order to mislead the authorities of the State in which they intend to claim asylum, and the protection of national security and public order. ${ }^{34}$

The Guidelines make clear that the grounds where detention may be "necessary" are narrowly confined. ${ }^{35}$ Verification of identity cannot be used to justify detention for the entire status

29 Hathaway, above, 113. See also, New Zealand Bill of Rights Act 1990, s 22.

30 Note that in New Zealand, unlawful detention is generally arbitrary, but there may be some exceptions. See $R v$ Goodwin (No 2) [1993] 2 NZLR 390, 394 (CA). In any case it will be necessary to consider the nature, purpose, extent and duration of the restraint. See Everitt v Attorney-General [2002] 1 NZLR 82, 87 (CA).

31 Executive Committee of the High Commissioner's Programme "Detention of Asylum-Seekers and Refugees: the Framework, the Problem and Recommended Practice" (Standing Committee $15^{\text {th }}$ meeting, Geneva, 4 June 1999) para 10.

32 Executive Committee of the High Commissioner's Programme "Detention of Refugees and AsylumSeekers" (Exedcutive Committee Conclusion No 44 (XXXVII), Geneva, 1986) <http://www.cmher.org> (last accessed ?).

33 The Court of Appeal in Attorney-General v E [2000] 3 NZLR 257 at 269 para 38 (majority), para 94 (Thomas J) recognised the authority of the Executive Committee in New Zealand.

34 See also UNHCR Revised Guidelines on Applicable Criteria and Standards Relating to the Detention of Asylum Seekers (UNHCR, Geneva, 1999) Guideline 3.

35 UNHCR Revised Guidelines on Applicable Criteria and Standards Relating to the Detention of Asylum Seekers (UNHCR, Geneva, 1999) Guideline 3. Note that although the guidelines may be relevant for interpretation purposes - particularly for judges exercising their discretion under ss 128 and 128A, they do not have the same status as the Conclusions of the Executive Committee of the UNHCR. Nor do they impose obligations on the Minister in considering applications for temporary permits by refugee status claimants. However, while they are not a binding international instrument, the Guidelines are part of the environment in which other more direct sources of law may be better understood. See Attorney-General v E [2000] 3 NZLR 257 (CA) para 39 (majority), and Abu v Superintendent of Mt Eden Women's Prison [2000] NZAR 260, para $37(\mathrm{HC})$. 
determination process, or for an unlimited period of time. As for asylum seekers without documents, their detention is only necessary where there has been an intention to deceive, and should not occur simply because they were unable to obtain the necessary documentation due to their persecution.

Detention to protect national security is only necessary where evidence shows that the asylum seeker has a criminal record or affiliations, and cannot be used as part of a policy to deter future asylum seekers or to dissuade others from continuing their claims. Detention is not to be used as a punitive or disciplinary measure for illegal entry or presence in a country. ${ }^{36}$

It follows that the measures applied must not go beyond what is necessary in a particular circumstance. Article 31.2 obliges Contracting States to differentiate their restrictive measures according to the circumstances. Detention should be the exception, rather than the rule. If a less severe restriction, such as ordering a refugee claimant to stay within a certain region, is available, this should always be employed first. ${ }^{37}$ This requires individual assessment of the personal circumstances of the asylum seeker, and the local conditions. ${ }^{38}$

\section{An appropriate balance?}

It may be thought that the Convention places too much weight on refugee rights and, if enforced, would leave little room for security measures. I do not subscribe to that view. I suggest that the Convention represents an appropriate balance between the two. If anything it could be adjusted in favour of refugee status claimants. ${ }^{39}$ For example, the narrow definition of "refugee" denies many worthy applicants protection.

36 UNHCR Revised Guidelines, above, Guideline 3.

37 Atle Grahl-Madsen Commentary on the Refugee Convention 1951 (Division of International Protection of the United Nations High Commissioner for Refugees, Geneva, 1997) 182.

38 UNHCR Revised Guidelines, above, Guideline 4

39 Andrew Langham describes the rights conferred by the Convention on refugees as weak, providing only limited guarantees, see "The Erosion of Refugee Rights in Australia" (1999) 8 Pac Rim L \& Poly 651, 653. It is certainly true that while many states pay lip service to the Convention, they invest considerable resources to keeping refugees away from their borders - for example Australia's (a state party to the Convention since 1954) dealings with the Tampa refugees. For a discussion of the legislative changes brought in at that time see Emily C Peyser "'Pacific Solution'? The Sinking Right to Seek Asylum in Australia" (2002) 11 Pac Rim L \& Poly 431; Alexander J Wood "The 'Pacific Solution': Refugees Unwelcome in Australia" (2002) 9 Hum Rts Br 22; and Nathan Hancock Refugee Law - Recent Legislative Developments (Current Issues Brief 5 2001-02, Parliament of Australia, 2001) $<$ http://www.aph.gov.au/library/pubs/cib/2001-02/> (last accessed 10 June 2003).

For a comparison between New Zealand and Australian refugee law see Jeanne Donald "We Don't Know How Lucky We Are, Mate: Australian and New Zealand Refugee Law - A Comparison" (12 April 2002) $<$ http://www.refugee.org.nz/lucky.html> (last accessed 10 June 2003). 
Regardless of whether they are detained or not, refugees do not find it easy. ${ }^{40}$ Article 31.2 recognises the special nature of refugees and the hardships they face by requiring greater justification for detention of refugees than other illegal aliens.

However, a State party is not obliged to admit any refugee claimant into its territory. ${ }^{41}$ While protecting refugees, the Convention also recognises the right of States to control their borders. Just fulfilling the Convention definition of "refugee" is, in itself, hard to do, as the statistics show. ${ }^{42}$ But the Convention goes further and is careful to avoid granting refugee status to either war criminals or those who might endanger the internal security of asylum countries, even if claimants otherwise fulfill the Convention definition. ${ }^{43}$ Further protection of national security is found in articles $9,{ }^{44}$ $32^{45}$ and $33(2) .46$

By giving effect to their Convention obligations, state parties are not curtailing their right to protect their borders, but are undertaking to do it in a fair way. The next question to be considered is to what extent New Zealand domestic legislation gives effect to these obligations, and the balance contained in them.

\section{DOMESTIC LEGISLATION}

A Extent to Which the Refugee Convention 1951 is Incorporated into the Immigration Act 1987 (Prior to 2002 Amendments)

New Zealand acceded to the 1951 Convention Relating to the Status of Refugees on 30 June $1960,{ }^{47}$ and the 1967 Protocol on 6 August $1973 .{ }^{48}$ However, it was not until 1999 that there was

40 See Stephen Price "A Long Way From Home" (14 December 2002) The Listener 22 for a discussion of what it is like to be a refugee in New Zealand.

41 Atle Grahl-Madsen Commentary on the Refugee Convention 1951 (Division of International Protection of the United Nations High Commissioner for Refugees, Geneva, 1997) 167.

42 Statistics found at $<$ http://www.refugee.org.nz/stats/htm $>$ (last accessed 10 June 2003).

43 See James C Hathaway The Law of Refugee Status (Butterworths, Toronto, 1991) 214 onwards.

44 Article 9 of the Convention allows a Contracting State, in time of war or other grave and exceptional circumstances, to take provisional measures which it considers to be essential to the national security in the case of a particular person, pending a determination by the Contracting State that that person is in fact a refugee and that the continuance of such measures is necessary in his case in the interests of national security.

45 Article 32 states that refugees may not be expelled from a Contracting State, except on grounds of national security or public order.

46 Article 33(2) allows cntracting state to expel or return (refouler) a refugee for whom there are reasonable grounds to regard as a danger to the security of a country in which he is seeking asylum, or a refugee who has been a convicted by a final judgment of a particularly serious crime, and constitutes a danger to the community of that country.

47 New Zealand Treaty Series 1961, No 2. 
any reference to these international instruments in the Immigration Act 1987. Section 60 of the Immigration Amendment Act 1999 attached the Refugee Convention and the 1967 Protocol to form the $6^{\text {th }}$ Schedule of the Act.

This does not necessarily mean, however, that a breach of its provisions will constitute a direct cause of action in the New Zealand courts. The orthodox position is that incorporation of some sort is needed before international documents will change domestic law. ${ }^{49}$ Mere annexation as a schedule is not usually enough, although Professor Burrows suggests that if it can be shown that Parliament's intent in annexing an international instrument was to enact it, this might be. ${ }^{50}$ Unfortunately there is insufficient evidence to support enactment by annexation in this case. ${ }^{51}$

Nor is there any express provision in the Immigration Act 1987 itself to suggest direct incorporation. In fact, Parliament expressly rejected UNHCR's submission to the Social Services Select Committee that section 129D be amended to give the Convention the force of law. ${ }^{52}$ New Zealand could have specifically adopted the Convention, and in particular Article 31. It chose not to do so. Nevertheless, its provisions still have some legal force. ${ }^{53}$

It is obvious from the Immigration Act 1987 (the Act) that the Convention has some application in New Zealand law. For example, the Convention definition of "refugee" has been adopted by section $129 \mathrm{~F}$ of the Act. Furthermore, under section 129D(1) refugee status officers and the Refugee Status Appeals Authority are required to act in a manner that is consistent with New Zealand's obligations under the Refugee Convention when carrying out their functions under Part VIA [Refugee Status Determinations].

There are some provisions falling outside Part VIA, and which make no explicit reference to the Convention. Does it still apply in those cases? The detention provisions in particular have caused concern because of this.

48 New Zealand Treaty Series 1973, No 21

49 See Attorney-General for Canada v Attorney-General for Ontario [1937] AC 326 (PC). See also, New Zealand Law Commission A New Zealand Guide to International Law and its Sources (Wellington, 1996) $11,14$.

50 John F Burrows Statute Law in New Zealand (2 ed, Butterworths, Wellington, 1999) 258.

51 Treasa Dunworth "Public International Law" [2000] NZ Law Rev 217, 229.

52 United Nations High Commissioner for Refugees "Submission to the Social Services Committee on the Immigration Amendment Bill 1998" (16 November 1998) para 2.

53 Ken J Keith "New Zealand Treaty Practice: The Executive and the Legislature" (1964) 1 NZULR 272, 298. See also the discussion of ways in which treaties can be relevant in Burrows, above, 293-298. 
Any person in New Zealand who is not a New Zealand citizen, who does not hold a permit, and who is not exempt from the requirement to do so, is deemed to be in New Zealand unlawfully. ${ }^{54}$ Such people may then be subject to detention pending departure on the first available craft under section 128(5). ${ }^{55}$ This has been used to detain refugee claimants and other illegal aliens alike. ${ }^{56}$

Detention can be authorised for up to 28 days, or longer by application to a District Court Judge. ${ }^{57}$ If detained under section 128 bail is generally unavailable unless review proceedings are brought. ${ }^{58}$ The 2002 amendments, discussed later, do however allow for conditional release.

It is clear that despite no explicit reference in section 128, the Convention is still relevant to detention decisions. Section $129 \mathrm{X}$ of the Immigration Act states that: ${ }^{59}$

(2) $[I] n$ carrying out their functions under this Act in relation to a refugee or refugee status claimant, immigration officers must have regard to the provisions of this Part and of the Refugee Convention.

This shows that the Convention is a relevant consideration for discretionary decision making throughout the Act. ${ }^{60}$ It is to be taken into account, not only when determining refugee status applications, but in the exercise of all functions, including consideration of applications for temporary permits, removal of persons unlawfully in New Zealand and associated powers of detention. $^{61}$

It is important to remember that the courts strive to give practical effect to international covenants, especially those concerning human rights, even in the absence of their incorporation into domestic law. ${ }^{62}$ Some international obligations are so manifestly important that they must be taken

54 Immigration Act $1987 \mathrm{~s} 4(2)$.

55 This is the general section for detention of people refused a permit. There are others that may apply. For example, people who pose particular security concerns such that their eligibility for a permit under $\mathrm{s} 7(1)$ is unclear are detained under s $128 \mathrm{~B}$ instead.

56 The question of whether it should have been used for refugees is discussed later in this article.

57 Immigration Act 1987 ss 128(7), 128(13) and 128(13B).

58 Immigration Act 1987 s 128A. In Refugee Council of New Zealand Inc v Attorney-General (No 2) [2002] NZAR 769 (HC) at para 4 Baragwanath J allowed bail despite s 128(15).

59 Section 129 of the Immigration Act $1987 \mathrm{X}$ is found in Part VIA, which was inserted by s 40 of the Immigration Amendment Act 1999.

60 Hon Justice Baragwanath "Judicial Review and Administrative Law Issues Arising in Refugee Law Cases in New Zealand" (Conference of International Association of Refugee Law Judges, Auckland, 10 March 2000) $4<$ http://www.lawcom.govt.nz> (last accessed 10 June 2003).

61 Attorney-General v E (2000) 3 NZLR 257, para 44 (CA).

62 Right Hon Dame Sîan Elias CJ "The Impact of International Covenants on Domestic Law" (Conference of International Association of Refugee Law Judges, Auckland, 10 March 2000) para 11-12 $<$ http://www.refugee.org.nz/IARLJ3-00Elias.html> (last accessed 10 June 2003). 
into account in decision making. Otherwise New Zealand's commitment to these obligations appears to be mere "window-dressing", an outcome that the Courts will do their best to avoid. ${ }^{63}$

At a Ministerial meeting of States Parties on 13 December 2001, New Zealand reaffirmed its commitment to implement its obligations under the Convention fully and effectively, in accordance with the object and purpose of the Convention and the 1967 Protocol. ${ }^{64}$ This cannot be rendered meaningless. The Convention is part of the Immigration Act 1987 and although not directly incorporated, must be regarded in detention decisions. The extent to which it must be regarded, was recently considered by the Court of Appeal, and their decision will now be discussed.

\section{THE REFUGEE COUNCIL CASE 65}

In this case, the Refugee Council and the Human Rights Foundation joined a former refugee claimant, "D", to challenge a Crown policy introduced on 19 September 2001 in response to the events of 11 September of that year. ${ }^{66}$ The Operational Instruction detailing the new policy concerned the discretion to detain refugee claimants under section 128 of the Immigration Act 1987. Coinciding with this Instruction was an increase in the number detained. In fact, between October 1999 and September 2001 less than 5 per cent of refugee status claimants were detained in custody on their arrival in New Zealand. After the change in policy, 94 per cent were detained. ${ }^{67}$

In the High Court Baragwanath J delivered two decisions; interim then supplementary. ${ }^{68} \mathrm{He}$ decided that while section 128 did apply to refugees, they could only be detained if the necessity test in Article 31(2) of the Convention were satisfied. ${ }^{69}$ He saw the Operational Instruction as mandating a "wholesale policy of detention", ${ }^{70}$ and thus unlawful.

63 Tavita $v$ Minister of Immigration [1994] 2 NZLR 257, 266 (CA).

64 Found at $<$ http://www.refugee.org.nz/archive2001.htm\#13\%20December\%202001a > (last accessed 10 June 2003)

65 Attorney-General v Refugee Council of New Zealand [2003] 2 NZLR 572.

66 This change in Crown policy was announced via a New Zealand Immigration Service (NZIS) Operational Instruction issued by the General Manager. Under s 13 of the Immigration Act 1987, the government is required to publish its immigration policy generally, and this is given effect to by the NZIS Manual published at $<$ http://www.immigration.govt.co.nz/operations manual $>$ (last accessed 10 June 2003) which is updated quarterly. Amendments may be found at this website, or can be sent directly to registered recipients.

67 Refugee Council of New Zealand Inc v Attorney-General (No 1) [2002] NZAR 717, para 17 (HC).

68 Refugee Council of New Zealand (No 1), above, 717; Refugee Council of New Zealand Inc v AttorneyGeneral (No 2) [2002] NZAR 769 (HC).

69 Refugee Council of New Zealand (No 2), above, 769, para 202 (HC).

70 Refugee Council of New Zealand (No 1), above, 717, para 111 (HC). 
The Attorney-General appealed the ruling on the Instruction, and the Refugee Council appealed the decision on section 128. The Court of Appeal delivered three judgments overturning in part Justice Baragwanath's decision. ${ }^{71}$

\section{A Reading of Section 128}

1 The application of section 128 to refugees

Section 128 allows for the detention in custody of any person who requires a permit and who arrives in New Zealand and is refused a permit, or fails to apply for one. Detention is allowed pending that person's departure from New Zealand on the first available craft. The Refugee Council contended that since section 129X of the Immigration Act 1987 prevents removal of refugees until their claims have been determined, they cannot leave on the first craft and, so the section cannot apply to them.

The Court of Appeal agreed with Baragwanath J that section 128 applied to refugees. ${ }^{72}$ The Court did not doubt that after the 1999 amendments, section 128(5) was to be read taking section 129X into account. However, the limitation is temporal rather than substantive. The "first available craft" must be read as the first available after a refugee claim is rejected. ${ }^{73}$ It does not mean that refugees fall outside the section's ambit. Both Attorney-General $v E^{74}$ and $D v$ Minister of Immigration ${ }^{75}$ supported this use of section $128 .^{76}$

Tipping $\mathrm{J}$ argued that if refugee claimants could not be detained, then they would be able to enter New Zealand unlawfully, which Parliament cannot have intended. ${ }^{77}$ While section $128 \mathrm{~B}$ deals with those who are security risks, it is not automatically appropriate for a refugee who does not fall within that section to be at large in New Zealand. ${ }^{78}$ McGrath J agreed that section 129B was not determinative of the detention powers in section $128 .{ }^{79}$

71 Tipping J was supported by Blanchard and Anderson JJ; McGrath and Glazebrook JJ gave their own judgments. See Attorney-General v Refugee Council of New Zealand [2003] 2 NZLR 572.

72 The Refugee Council case (Court of Appeal), above, para 19 Tipping J, para 96 McGrath J, and para 241 Glazebrook J.

73 The Refugee Council case (Court of Appeal), above, para 12 Tipping J.

74 Attorney-General v E [2000] 3 NZLR 257 (CA).

75 D v Minister of Immigration [1991] 2 NZLR 673 (CA).

76 The Refugee Council case (Court of Appeal), above, para 17 Tipping J, para 75-80, 90 McGrath J and para 230, 255 Glazebrook J.

77 The Refugee Council case (Court of Appeal), above, para 10.

78 The Refugee Council case (Court of Appeal), above, para 11.

79 The Refugee Council case (Court of Appeal), above, para 91. 
Both Tipping and McGrath JJ found further support for an application of section 128 to refugees in section 128(13B), introduced by the 1999 amendments. This section gives an express power to extend the warrant for more than seven days in the case of mass arrivals. The Parliamentary debates show that this section intended to cover refugees. Parliament must have intended that refugees could be detained under section $128(5)$ for subsection $13 \mathrm{~B}$ to make sense. ${ }^{80}$

Glazebrook $\mathrm{J}$ undertook a detailed analysis of the legislation, its judicial interpretation, and its history. She found that the old legislation did not include refugees, and when first introduced, the Immigration Act 1987 arguably might not have included them either. However, the 1999 amendments to section 128 changed the position so that it clearly applied to refugees. AttorneyGeneral $v E^{81}$ supports this application, and Glazebrook J considered it inappropriate to depart from the recent Court of Appeal case on this point. ${ }^{82}$

2 Construction of the detention powers under section 128(5)

Accepting that refugees can be detained under section 128, the next question was how the Convention impacted on this power, if at all. In the High Court, Baragwanath $J$ found that in accordance with Article 31(2) refugees could be detained under section 128 of the Immigration Act 1987 only where necessary. This would occur in the rare situations where there is a real risk of criminal offending or absconding, or where detention was necessary to allow the Refugee Status Branch to perform their functions. ${ }^{83}$

In the Court of Appeal McGrath and Glazebrook JJ found Baragwanath J's test too strict. In their opinion it did not accord with the UNHCR Executive Committee's view of the Convention. ${ }^{84}$ Tipping $\mathrm{J}$ did not directly address the issue.

McGrath J noted that section 129X(2) does not give Article 31 the force of law in New Zealand. Parliament chose not to do so and it would be wrong to give it such force now. Instead Article 31(2), as elaborated by the Executive Committee in its 1986 Conclusion No 44, must "... be given genuine attention and thought by immigration authorities". ${ }^{85}$ It is a value to be regarded, but not the only one.

80 The Refugee Council case (Court of Appeal), above, para 14 - 15.

81 Attorney-General v E [2000] 3 NZLR 257 (CA).

82 The Refugee Council case (Court of Appeal), above, para 238.

83 Refugee Council of New Zealand Inc v Attorney-General (No 2) [2002] NZAR 769, para 125-126 (HC).

84 The Refugee Council case (Court of Appeal), above, para 102 McGrath J, para 257 Glazebrook J.

85 The Refugee Council case (Court of Appeal), above, para 97. 
McGrath J noted that Parliament must have intended for people refused permits to be detained, although later release into the community is allowed in accordance with the statutory regime. ${ }^{86}$ As such, individual circumstances relating to the need for detention, and also our obligations under the Convention, should be considered when deciding whether to grant a permit. ${ }^{87}$ If section $129 \mathrm{X}(2)$ is complied with at the permit stage, and no new factors are brought to light, then the decision not to grant a permit may be relied on as the basis for detention. ${ }^{88}$

Glazebrook J highlighted the fact that the Convention is not the sole determinant of detention when section $129 \mathrm{X}(2)$ is considered. Even if it were, the test changes according to the severity of the restraint. ${ }^{89}$ However, she did note that any other factors in a section 128 decision, must take into account that detention deprives liberty. It must be assumed that Parliament intended section 128 of the Immigration Act 1987 to be in line with section 22 of the New Zealand Bill of Rights Act 1990 which protects the right not to be subject to arbitrary detention. ${ }^{90}$

\section{Discussion}

The section 128 interpretation difficulties demonstrate the awkwardness of legislation that covers too much. Refugees have special concerns and deserve special treatment. This makes it difficult, and perhaps inappropriate, to cover refugees' needs in the same legislation used for other illegal immigrants. Despite repeated opportunities, Parliament has declined to accept the suggestion of the Court of Appeal in D v Minister of Immigration ${ }^{91}$ that specific legislation for detention of refugees be enacted; instead it has maintained the current framework through several amendments. $^{92}$

The way the Court handled these difficulties regarding section 128 is sensible and unsurprising. If section 128 did not apply to refugees the balance would have swung too far in their favour, at the

86 The Refugee Council case (Court of Appeal), above, para 108.

87 The Refugee Council case (Court of Appeal), above, para 109.

88 The Refugee Council case (Court of Appeal), above, para 109.

89 The Refugee Council case (Court of Appeal), above, para 275.

90 The Refugee Council case (Court of Appeal), above, para 256.

91 D v Minister of Immigration [1991] 2 NZLR 673 (CA).

92 For a discussion of Refugee legislation in Australia, see Emily C Peyser "'Pacific Solution'? The Sinking Right to Seek Asylum in Australia" (2002) 11 Pac Rim L \& Poly 431, Nathan Hancock Refugee Law Recent Legislative Developments (Current Issues Brief 5 2001-02, Parliament of Australia, 2001) $<$ http://www.aph.gov.au/library/pubs/cib/2001-02/02cib05.htm> (last accessed 10 June 2003).

For a comparison between New Zealand and Australian refugee law see Jeanne Donald "We Don't Know How Lucky We Are, Mate: Australian and New Zealand Refugee Law - A Comparison" (12 April 2002) $<$ http://www.refugee.org.nz/lucky.html > (last accessed 10 June 2003). 
expense of national security. Even the Convention allows brief initial detention to determine identity. ${ }^{93}$

As regards the construction of detention powers, the Court was clearly right to give the Convention weight, although perhaps not enough. I agree that the right of refugees not to be detained is not the only relevant factor, but the others have already been built into the necessity test contained in the Convention. As discussed earlier in this article, the appropriate balance has already been struck.

The problem was not the weight that Baragwanath $\mathrm{J}$ gave to the Convention, but rather his reading of "necessity". The Executive Committee Conclusion $44^{94}$ and The Guidelines ${ }^{95}$ both allow detention for the protection of national security or public order, which is wider than a real risk of criminal offending or of absconding. And, as Glazebrook $\mathrm{J}$ pointed out, the type of detention also affects the necessity test.

Baragwanath J's strict test may also go against the Court of Appeal judgment in AttorneyGeneral $v E,{ }^{96}$ from which the Court seemed reluctant to depart. In that case, thirteen plaintiffs arrived in New Zealand over a period and claimed refugee status on arrival. They also applied for temporary entry permits pending determination of their claims. Their applications were denied and they were detained in prison. They challenged their decision relating to the temporary permits by way of judicial review.

The majority in the Court of Appeal held that while the immigration officers had to consider the provisions of the Convention and the Immigration Act 1987, there was nothing in either to require a presumptive approach in the discretion of the Minister of Immigration, or his or her delegate to grant a temporary permit to a refugee status claimant, even if the UNHCR Guidelines were read in. 97

93 Executive Committee of the High Commissioner's Programme "Detention of Refugees and AsylumSeekers" (Executive Committee Conclusion No 44 (XXXVII), Geneva, 1986) <http://www.unhcr.org $>$ (last accessed 29 June 2003)

94 "Detention of Refugees and Asylum-Seekers", above.

95 UNHCR UNHCR Guidelines on Applicable Criteria and Standards Relating to the Detention of Asylum Seekers (UNHCR, Geneva, 1999).

96 Attorney-General v E [2000] 3 NZLR 257, para 48 (CA).

97 Attorney-General v E [2000] 3 NZLR 257, para 47 (CA) Richardson P, Gault, Henry and Keith JJ. 
The strict necessity test creates a very strong presumption against detention, and thus effectively creates a presumption in favour of the only other option under section 128 at the time - granting a permit. ${ }^{98}$ This is precisely what the Court of Appeal in Attorney-General, previously rejected.

While Glazebrook $\mathrm{J}$ also mandates a necessity test in the application of section 128(5), she deals with the above problem by saying that detention is not the automatic consequence of refusal of a permit. Legally and practically, refugees can be released without a permit. However, the fact that the claimant will then be at large in New Zealand is a relevant factor in the detention decision. ${ }^{99}$

On the other hand, McGrath J suggests that where no new information is brought to light, the detention decision can be based entirely on the fact that no permit was granted. ${ }^{100}$ Glazebrook J's approach is surely more appropriate as it gives an additional check in the process, which is important when human rights are at stake.

\section{B NZIS Operational Instruction - A Policy of Detention?}

\section{The Court's Decision}

The second major ground for review in the Refugee Council case was Baragwanath J's finding that the Operational Instruction was unlawful. Baragwanath J's decision was based on his strict necessity test. He found that while detention may be necessary to prevent some claimants from absconding, it is in no way necessary for all, or even a great number of claimants. ${ }^{101}$ Therefore, Baragwanath $\mathrm{J}$ decided that their invariable automatic detention cannot be "necessary". ${ }^{102}$

The Court of Appeal overturned the High Court ruling. When the Operational Instruction was read as a whole, rather than focussing on individual phrases, or trying to apply to individual cases, there was nothing unlawful. ${ }^{103}$ In fact Tipping $\mathrm{J}$ was "... surprised at the assertion, let alone the conclusion ..." that it might have been unlawful. ${ }^{104}$

98 See Asher Davidson Article 31(2) of the Refugee Convention and its Implementation in New Zealand: Is Detention Defensible? (LLB(Hons) Dissertation, University of Auckland, 2000) para 112.

This situation has, of course, been remedied for the future by the Immigration Amendment Act 2002, which allows for conditional release.

99 Attorney-General v Refugee Council of New Zealand [2003] 2 NZLR 572, para 289.

100 The Refugee Council case (Court of Appeal), above, para 109.

101 Refugee Council of New Zealand v Attorney-General (No 1) [2002] NZAR 717, para 85 (HC).

102 Refugee Council of New Zealand (No 1) above, 717, para 107 (HC).

103 The Refugee Council case (Court of Appeal), above, para 26 Tipping J, para 119 McGrath J, and para 285 Glazebrook J.

104 The Refugee Council case (Court of Appeal), above, para 26. 
The Court was unanimous in stating that the Instruction did not, as Baragwanath J had found, deal only with where to detain, but also with whether to detain at all. The whole first section was directed towards a presumption against detention, which can only be departed from in certain circumstances. When the second part is read in this light there is no illegality. The obligation in section 129X(2) of the Immigration Act 1987 to have regard to Article 31(2) was met in the first section of the Instruction which made direct mention of the Article. ${ }^{105}$

While agreeing that there was nothing unlawful if the Instruction was read properly, Glazebrook $\mathrm{J}$ did recommend some changes. The first part of the Instruction should be phrased as a question of whether to issue a permit, rather than whether to detain. She recommended changing the second part of the Instruction so that it differentiated the question of whether to detain, from the question of where to detain. ${ }^{106}$ Furthermore, the part dealing with refugees whose identity is uncertain should make clear that there is no presumption in favour of detention based on this factor alone. ${ }^{107}$

Glazebrook $\mathrm{J}$ recognised that the UNHCR Guidelines allow the necessity standard to vary according to the severity of the restrictions placed on freedom of movement. ${ }^{108}$ Nevertheless, Guideline Four still implicitly requires a reasonably high threshold for open centres, being the least desirable alternative to detention. ${ }^{109}$

Applying this to the Operational Instruction, Glazebrook $J$ thought the test for detention in the Mangere Centre did not need to be so stringent as for in a penal institution. The Instruction set a higher standard for the latter, and for either institution the Instruction was clear that it did not mandate detention but required a balancing exercise. ${ }^{110}$ The Instruction required an assessment of all the circumstances, including the considerations in the first part regarding whether to detain at all. This was in line with the Convention. ${ }^{111}$

The Court was unanimous that individual circumstances of D's case also showed no unlawfulness in the way the Instruction was applied. ${ }^{112}$ In any case, Tipping $J$ thought it

105 Attorney-General v Refugee Council of New Zealand (2003) 2 NZLR 572, para 118.

106 The Refugee Council case (Court of Appeal), above, para 285 - 286.

107 The Refugee Council case (Court of Appeal), above, para 283.

108 The Refugee Council case (Court of Appeal), above, para 275. McGrath J also accepted that the availability of the Mangere Accomodation Centre may justify lawful detention in circumstances where earlier there would have been hesitation at para 119 .

109 The Refugee Council case (Court of Appeal), above, para 264.

110 The Refugee Council case (Court of Appeal), above, para 276.

111 The Refugee Council case (Court of Appeal), above, para 275.

112 The Refugee Council case (Court of Appeal), above, para 40 Tipping J, para 122 McGrath J, and para 299 Glazebrook J. 
inappropriate to consider how individual cases had been dealt with, when determining the lawfulness of the Instruction. A proper construction of its terms was the important test, and this showed nothing unlawful. ${ }^{113}$

While the Court was naturally concerned that the number of refugees detained had increased over the period in question, Tipping was clear that it would be improper "... for the Court to reach any conclusion simply on the basis of the statistical materials, particularly when they are drawn from a period immediately following an event such as September 11". ${ }^{114}$

McGrath J made clear that their findings on the lawfulness of the Operational Instruction and of D's detention undermined Baragwanath J's decision that there was an unlawful general policy of detention. ${ }^{115}$ Even if it could be shown that the overall policy was unlawful, Glazebrook J pointed out that this would not affect the legality of individual detention decisions. ${ }^{116}$ These would still have to be examined on their facts.

\section{Discussion}

I do not share the Court's confidence that the words of the Instruction can be separated from the outcome detaining 94 per cent of refugee claimants. Glazebrook J acknowledges that the Instruction is confusing and recommends changes that underline some fundamental problems. Her changes suggest that it could indeed be read as mandating a presumption in favour of detention, or as ignoring the question of whether detention is actually necessary. However, as the Court was able to read it in such a way that it was lawful, this was enough. Never mind that it is clearly quite possible to read it in another way, and that the statistics suggest it has indeed been read and applied in this unlawful manner.

Nevertheless, I can understand the reluctance of the Courts to rely on statistics alone. The Judges do at least recognise that there is some cause for concern, but refuse to rule on the general policy. ${ }^{117}$ While there is some possibility of an appeal, ${ }^{118}$ the facts of D's case, the only set of individual circumstances before the Court, do not help to show that the application was unlawful. And if his or her case was dealt with properly, it is at least possible (if unlikely) that every other case was too.

113 Attorney-General v Refugee Council of New Zealand (2003) 2 NZCR 572, 30.

114 The Refugee Council Case, above, 47. Glazebrook J agreed at para 300 that no definitive finding on the detention policy could be made.

115 The Refugee Council Case, above, para 123.

116 The Refugee Council Case, above, 301.

117 The Refugee Council Case, above, para 46 Tipping J, and para 300 Glazebrook J.

118 "Courts back Detaining Refugees" (17 April 2003) The Dominion Post Wellington 5. 
I also understand that immigration involves difficult balancing exercises and the Courts are understandably reluctant to intervene absent illegality. However, there is a worrying practice of successive New Zealand governments to take overly protective measures in a panic response to perceived threats to national security. Some general comment is deserved.

This trend can be identified in the security procedures adopted during the first Gulf War for determining refugee status applications, which required the police to consider whether someone was not a threat to national security; if they could not be satisfied the claimant would be deported. The result was that asylum-seekers were denied clearance on the basis that not enough was known about them, rather than that there were reasonable grounds for considering them a security threat under Article 33(2). ${ }^{119}$

The trend continued during the APEC conference in 1999, when all asylum seekers were detained in Auckland Central Remand Prison. This decision drew international criticism. ${ }^{120}$

And again, the practice is apparent in the enactment of the Immigration Amendment Act (No 2) 1999. This Act was passed under urgency in response to the threatened arrival of 102 Chinese by boat. It implemented the detention provisions of the Immigration Amendment Act (No 1) 1999 at an earlier date than the rest of the Act, which counterbalanced the detention provisions. Politicians labelled it a panic move in response to the Chinese boat people, which required ignoring the spirit of the Convention. ${ }^{121}$

The measures taken in response to September 11 complete the quinella.

Undoubtedly September 11 (and the earlier events) required a governmental response regarding immigration. To do so was not inconsistent with the Convention, which allows provisions to be made for national security. Indeed, there would be few signatories if it did not. However, the Convention requires that any measures to protect national security be in response to the circumstances of the individual and the local conditions. ${ }^{122}$ I am not convinced that this happened in all 208 cases dealt with using the Operational Instruction. The confusing wording and the suddenly high rate of detention suggest the balance had swung away from refugee rights, despite the Court of Appeal's findings.

119 Rodger Haines QC "International Law and Refugees in New Zealand" [1999] NZ Law Rev 119.

120 Human Rights Foundation of Aotearoa New Zealand and Refugee Council of New Zealand Inc "Freedom's Ramparts on the Sea: The Detention of Asylum Seekers in New Zealand" (May 2002) 23 $<$ http://www.humanrights.co.nz/docs/freedoms ramparts.doc $>$ (last accessed 10 June2003).

121 Matt Robson (15 June 1999) 578 NZPD 17354

122 UNHCR UNHCR Revised Guidelines on Applicable Criteria and Standards Relating to the Detention of Asylum Seekers (UNHCR, Geneva, 1999), Guideline 4. 


\section{IMMIGRATION AMENDMENT ACT 2002}

Recent legislative changes may go some way in correcting this imbalance by allowing refugees to apply for conditional release. These changes will first be outlined, then evaluated in light of refugee rights.

\section{A History of the Act}

The Immigration Amendment Act 2002 was a response to the events on September 11. It was originally contained in the Transnational Organised Crime Bill 2002 ("the Bill"), which created offences in respect of, and otherwise discouraged, certain types of transnational crime. The Bill also sought to implement obligations in the United Nations Convention against Transnational Organised Crime and its Protocols on the Smuggling of Migrants and Trafficking of Persons, which New Zealand signed in December 2000.

This Bill was criticised for introducing a number of provisions not directly related to migrant smuggling and for using "... hysteria about foreigner dangers to slide through unnecessary threats to New Zealanders' freedoms and the rule of law". ${ }^{123}$ It was alleged that many unnecessary, or overly stringent measures would thereby be introduced via the back door.

To meet these criticisms, the Bill was divided into five separate Acts at its third reading, one of which was the Immigration Amendment Bill 2002. This was assented to on 17 June 2002, and came into force the next day. Sections 9 and 10 of the Amendment Act modified the position of section 128 of the Immigration Act 1987 and the detention of refugees.

\section{$B$ Sections 9 and 10}

The Immigration Amendment Act 2002 has no purpose section. However, it is clear from the content of sections 9 and 10, and also from the comments of the Hon Phil Goff during question time, that these sections were included to address the "unduly restrictive" approach to bail under section $128 .^{124}$

Sections 9 and 10 of the 2002 Amendment Act aim to provide a middle ground between detention under section 128 of the Immigration Act 1987, and release into the community with a permit. They promote the rights of refugee status claimants according to the Refugee Convention and the New Zealand Bill of Rights Act 1990, while still allowing New Zealand to manage the risks associated with persons claiming refugee status at the border. ${ }^{125}$

123 Stephen Franks MP "Sinister Add-Ons to Terrorism, Boat People Bills" (1 March 2002) Press Release.

124 In particular under the old section 128 bail was only available to those who applied for judicial review of their detention under section 128A. Hon Phil Goff (11 June 2002) 601 NZPD 16766.

125 Transnational Organised Crime Bill 2002, no 201-1 (the commentary) 13; Hon Phil Goff (30 May 2002) 601 NZPD 16727. 
Section 9 concerns the detention and departure of persons refused permits. It repeals section 128(15), which denied bail to a person detained under section 128, and substitutes a new subsection 15 , which continues to deny bail, but enables a person detained under that section to be released under section 128A, or the new section 128AA. This means that persons detained under section 128 no longer have to apply for judicial review under section $128 \mathrm{~A}$ to be released, for which there is no legal aid available.

Section 10 sets out the new sections 128AA - 128AD. Section 128AA allows an immigration officer, or a refugee claimant detained under section $128(5),{ }^{126}$ or a person subject to an application for extension of the warrant of commitment, to apply to a District Court judge for an order of conditional release. ${ }^{127}$

If the judge declines to order release, then provided the person is not already subject to an order under section 128(7), a warrant of commitment must be issued authorising the person's detention for a period of not more than 28 days. ${ }^{128}$

Where an application to extend the warrant of commitment already exists and the Judge declines to order conditional release, he or she may extend the warrant for up to seven days. ${ }^{129}$ However, if the person is part of a mass arrival, all of whom are applying for conditional release, the judge may extend or further extend the warrant for such period as the judge thinks necessary in the circumstances to allow the group concerned to be properly dealt with. ${ }^{130}$

The new section $128 \mathrm{AB}$ sets out the conditions of an order of conditional release under section 128AA(6). The judge is free to impose any circumstances, in addition to the residence and reporting times stated in the section, as he or she sees fit.

Section 128AC(7) states that any person released under section 128AA is to continue to be treated as detained under section 128, and nothing in Part II (relating to persons in New Zealand unlawfully and allowing appeal against the requirement to leave) applies to such a person.

126 Immigration Act 1987, s 128AA(4). This was inserted in Committee on 11 June 2002 by the amendment of Keith Locke. This is a considerable advantage as it means that refugee claimants do not have to wait 28 days to apply for release.

127 Immigration Act 1987, s 128AA(3) for people not claiming refugee status, and s 128AA(4) for refugee claimants. See s $128 \mathrm{AA}(2)(\mathrm{b})$ for those already subject to an application to extend their warrant.

128 Immigration Act 1987, s 128AA(8)(a).

129 Immigration Act 1987, s 128AA(8)(b)(ii).

130 Immigration Act 1987, s 128AA(8)(b)(i) 


\section{Concerns for Refugees}

According to the Explanatory Note to the Transnational Organised Crime Bill, the obligations of state parties to the Refugee Convention are not altered by the Migrants Protocol, which the Bill aimed to implement. ${ }^{131}$ Nor did the Bill itself alter these obligations. ${ }^{132}$ Thus, our international obligations regarding refugees have not changed despite increasing security concerns. Whether the new provisions meet those obligations is a moot point, and probably ultimately depends on the interpretation of the Courts.

Baragwanath J thought that: ${ }^{133}$

Clause 25 of the [Transnational Organised Crime] Bill [inserting new sections 128AA - 128AD] includes an amendment to the Immigration Act. It will, if enacted, provide additional flexibility in dealing appropriately with persons claiming refugee status at the border upon arrival, in the light of their personal circumstances and identity, security, repatriation and other concerns.

It is to be hoped that, in considering whether to grant conditional release, District Court judges will consider the factors highlighted by Baragwanath $\mathrm{J}$, but there is nothing in the Immigration Amendment Act 2002 to ensure that they do. In its select committee submission, the Refugee Council recommended that if clause 25 was to remain, section 128AA(6) should stipulate criteria to be considered. They submitted that this was necessary for certainty, as required by the rule of law, the Refugee Convention and the Bill of Rights. ${ }^{134}$

However, in its report to the Foreign Affairs, Defence and Trade Committee on the Transnational Organised Crime Bill the Department of Labour rejected this suggestion. It considered it inappropriate, saying that release requires the balancing of many factors, which differ according to the circumstances of the case. ${ }^{135}$

Even so, I think that there should be a requirement that judges consider the individual circumstances of the case and have regard to the Refugee Convention in doing so. ${ }^{136}$ For example, if a District Court judge declines conditional release of mass arrivals, they may extend the warrant

131 Transnational Organised Crime Bill 2002, no 201-1 (explanatory note) 3 .

132 Hon George Hawkins (28 February 2002) 598 NZPD 14756.

133 Refugee Council of New Zealand v Attorney-General (No 1) [2002] NZAR 717, para 75 (HC).

134 Refugee Council of New Zealand Inc "Submission to the Foreign Affairs, Defence and Trade Committee on the Transnational Organised Crime Bill 2002" para 49.

135 Department of Labour Departmental Report on Submissions to the Foreign Affairs, Defence and Trade Committee on the Transnational Organised Crime Bill 2002 (Department of Labour, Wellington, 2002) 8.

136 This should not be too problematic. See for example, Bail Act $2000 \mathrm{~s} \mathrm{8,} \mathrm{which} \mathrm{lists} \mathrm{the} \mathrm{criteria} \mathrm{that} \mathrm{judges}$ must take into account in every bail application. And surely bail is no different from conditional release applications in requiring differing factors to be balanced and the circumstances of the case to be considered? 
of commitment for such period as he or she considers necessary to deal with the whole group. This means that individual circumstances may not be considered, only the fact that the refugee claimant is part of a mass arrivals. ${ }^{137}$ Furthermore, their detention does not need to be reviewed every seven days and could potentially last indefinitely or for the whole status determination period. This goes directly against Article 31(2) of the Convention.

Another concern is the effectiveness of applications to District Court judges for release. The NZIS considered that, as regards detention under section $128::^{138}$

There is no requirement for a Judge to extend the warrant merely because an extension is sought. The fact that a case had not been processed expeditiously would clearly constitute grounds for a Judge to consider that detention of an asylum seeker pending determination of his or her claim might no longer be justified. Any detention resulting from a warrant issued pursuant to $\mathrm{s} 128$ is clearly prescribed by law.

However, the evidence accepted in the High Court by Baragwanath $\mathrm{J}$ in the Refugee Council case about the almost invariable practice by District Court Judges of extending warrants when asked to, throws these statements into question. ${ }^{139}$ Will an application for conditional release prove a more robust safeguard?

Rather than conditional release on what amounts to bail, (even if not so called), the UNHCR favours a presumption against detention in the first place: ${ }^{140}$

The degree to which asylum-seekers can effectively challenge the lawfulness of their detention, however, varies significantly. In many States, asylum-seekers are expected to initiate the review process themselves, by applying for bail or parole, which often poses difficulties given their unfamiliarity with the legal process and, in many cases, their inability to speak the language. These difficulties are even more acute when assistance in the form of legal aid is not available. In order to ensure that the rights of asylum-seekers are respected in this regard, there should be prompt, mandatory and periodic review of all detention orders before an independent and impartial body.

137 Note Glazebrook J's concern of Attorney-General v Refugee Council of New Zealand [2003] 2 NZLR 572, para 284 that Immigration Officials must be made aware that detention must be necessary for each member of the group, and that if it is necessary, it lasts for the shortest time possible.

138 New Zealand Immigration Service "Immigration Amendment Bill 1998 - Departmental Report to the Social Services Committee" 23.

139 Refugee Council of New Zealand v Attorney-General (No 1) [2002] NZAR 717, para 101-102 (HC).

140 Executive Committee of the High Commissioner's Programme "Detention of Asylum-Seekers and Refugees: the Framework, the Problem and Recommended Practice" (Standing Committee 15th meeting, Geneva, 4 June 1999) para $16-17$. 
UNHCR shares the opinion of the Working Group on Arbitrary Detention that in States where such challenges are by way of bail hearings "asylum-seekers may have no effective opportunity to challenge the reasons for the detention, as the focus would be on establishing the reliability of the surety and its relationship to the applicant as opposed to the reasons for the detention".

In New Zealand a key problem remains that legal aid is not available to challenge detention. While section 128AA of the Immigration Act 1987 provides conditional release, it does not go to the legality of the original detention. However, to provide legal aid at this stage would involve a reversal of the policy decisions of 1999, which extended legal aid in relation to refugee status claims, but, in response to perceived abuse of the system, removed it for other immigration matters not involving residents. ${ }^{141}$ Nevertheless, Hon Lianne Dalziel, Minister of Immigration, said that while the Immigration Amendment Act 2002 was not directed towards legal aid, she could commit Parliament to looking into funding legal representation for refugee status clamaints regarding detention, although not necessarily through the grant of legal aid. ${ }^{142}$

\section{THE RELATIONSHIP BETWEEN THE IMMIGRATION AMENDMENT ACT $A N D$ THE REFUGEE COUNCIL CASE}

One of the main concerns expressed at select committee about the proposed legislation was that it was seen as justifying the use of section 128 to detain refugees, which was at the time being challenged in the High Court in the Refugee Council case. ${ }^{143}$ Furthermore, as originally drafted, section 128AA allegedly extended the power of detention under section 128 to include refugee claimants by back door tactics - at that time only mentioning refugee status claimants in a minor provision: section $128 \mathrm{AB}(1)(\mathrm{b}){ }^{144}$ However, this was changed, and now section 128AA(2) makes it clear that refugees are subject to these provisions.

While it is inherently undesirable for the outcome of litigation to be pre-empted in such a way, the problem is not so great in this case as both the High Court and the Court of Appeal decided that section 128 applies to refugee status claimants anyway. Justice Baragwanath even invited legislative response to deal with conditional release of refugees. ${ }^{145}$

141 Department of Labour Departmental Report on Submissions to the Foreign Affairs, Defence and Trade Committee on the Transnational Organised Crime Bill 2002 (Department of Labour, Wellington, 2002$) 8$.

142 Hon Lianne Dalziel (11 June 2002) 601 NZPD 16830. It appears no progress has been made on this issue.

143 See Refugee Council of New Zealand Inc v Attorney-General (No 1) [2002] NZAR 717; Refugee Council of New Zealand Inc v Attorney-General (No 2) [2002] NZAR 769 (HC).

144 Refugee Council of New Zealand Inc "Submission to the Foreign Affairs, Defence and Trade Committee on the Transnational Organised Crime Bill" para 22.

145 Refugee Council of New Zealand v Attorney-General (No 1) [2002] NZAR 717, para 25 (HC). 
It is now clear that section 128 does apply to refugee claimants. What can be questioned is how the new legislation and the Refugee Council case will interact, if at all. The most likely outcome is that the effect of the Refugee Council case will be limited to cases under the pre-2002 amendment legislation. All future refugee claimants arriving without a permit will be detained pursuant to section 128(5), but will then be able to apply for conditional release under section 128AA.

Once there is the option of conditional release, the factors laid out for consideration by the Court of Appeal in a section 128(5) decision will be ignored. ${ }^{146}$ The only criterion for detention is a spontaneous claim to refugee status, in which case a permit will be refused on arrival in New Zealand. This arguably breaches not only the Convention, but also sections 21 and 22 of the Bill of Rights Act $1990 .{ }^{147}$ Furthermore, wrongly detained refugee status claimants do not get the benefit of the complaints system under the Human Rights Act 1993. ${ }^{148}$

The Immigration Amendment Act 2002 allows detention for everyone who arrives in New Zealand unlawfully, but with the conditional release of all except those whom it is necessary to detain. While this might not seem that different from doing the balancing act before detention, the differences could be very important in the future. If detention is retained as the first step for all refugee claimants it is much easier to justify a change in policy such as the one seen after September 11 of not releasing anyone on bail. If the position were that only those necessary to detain were detained from the outset it would be much harder to shift policy to detain everyone. Under this analysis, bail could be seen as mere "sugar-coating" of a policy of detention. ${ }^{149}$

This is the outcome feared by Keith Locke MP in his speech at the Transnational Organised Crime Bill's second reading: ${ }^{150}$

The changes we are making include a system of conditional release for imprisoned asylum seekers that on the one hand might seem a step forward, but on the other hand could be part of a process of

146 See however $A v$ New Zealand Police (26 July 2002) High Court Auckland R90/02 Baragwanath J where he suggested that even after the Immigration Amendment Act 2002, the "necessity" test expounded in the High Court still needed to be applied for detention decisions before the question of conditional release. Of course this was before the Court of Appeal decision in the Refugee Council Case.

147 Refugee Council of New Zealand Inc "Submission to the Foreign Affairs, Defence and Trade Committee on the Transnational Organised Crime Bill" para 24.

148 See Immigration Act 1987, s 149D as amended by the Human Rights Amendment Act 2001, s 55.

These exemptions are much narrower than previously existed under the Human Rights Act 1993, s 153(3) and the previous Immigration Act 1987, s 149D which basically banned any application of the former to the latter. At least now the Human Rights Commission will be able to inquire into matters and make public statements and so on. However, the exemptions still prevent refugees from making a complaint under the Human Rights Act 1993, which is the most valuable part.

149 Keith Locke (11 June 2002) 601 NZPD 16767.

150 Keith Locke (30 May 2002) 601 NZPD 16736. 
legitimising the routine imprisonment of asylum seekers, whereby virtually all asylum seekers who arrive in this country are put in prison, often for long periods of several months, which is a huge injustice for people who have suffered so much overseas before they get here.

However, considering that these measures were part of a transnational security drive, it is unsurprising that the emphasis is in favour of security. This means that someone is more likely to be detained when it was not necessary (and their rights breached) than someone released who should not be (and national security threatened). This can, perhaps, be justified as protecting the collective right of all New Zealanders to liberty and freedom from harm, over the right of individuals to liberty.

In any case, it has to be accepted that the enactment of sections 128AA to 128AD is an improvement on the previous situation, so long as they are properly used. ${ }^{151}$ They at least provide an alternative to detention or release into the community with a permit. Prior to the Immigration Amendment Act 2002, detainees could only be released by habeas corpus or judicial review proceedings, for which legal aid was not available.

\section{CONCLUSION}

The right to control borders is an important aspect of state sovereignty, and is jealously guarded. ${ }^{152}$ It requires decisions to be made about who enters the country, and what methods will be employed to stop those who are not desired from doing so. Detention is an effective way of preventing unwanted entry.

Conversely, liberty is a fundamental human right, which needs to be balanced against this right of the State. Where people try to enter a state unlawfully limitations on the right to freedom may well be justified. However, in the case of refugees greater justification is required. New Zealand voluntarily acceded to the 1951 Refugee Convention, and has recently reaffirmed its commitment. It must then respect the consequences of such undertakings.

Article 31 of the Convention provides that refugee status claimants should not be detained, other than in strictly circumscribed instances of necessity. While not directly incorporated into New Zealand domestic law, the Convention is still important and must be regarded.

Section 128 of the Immigration Act 1987 and the way it was interpreted in governmental policy prior to the Refugee Council case did not give effect to Article 31. It could have been argued that this expressly overrode it. This would mean that while other parts of the Convention had been specifically imported into New Zealand law, Article 31 had no relevance.

151 See "Policy Puts off Asylum Seekers" (16 August 2002) The Dominion Post Wellington A7, which suggests that new arrivals are still being detained without conditional release.

152 Atle Grahl-Madsen Commentary on the Refugee Convention 1951 (Division of International Protection of the United Nations High Commissioner for Refugees, Geneva, 1997) 168. 
However, recent developments have shown that this is not the case. Clearly Article 31 has a bearing on New Zealand domestic law. In the Refugee Council case, the Court of Appeal found that although refugees may be detained under section 128, this requires consideration of our Convention obligations. The Immigration Amendment Act 2002 also requires that conditional release from detention only be denied where necessary.

While these developments change this awkward application of section 128 to refugee status claimants, and are to be commended for bringing New Zealand closer to her international obligations under Article 31, there is still room for improvement. But so long as refugees and other illegal migrants are not distinguished in the legislation, the problems will continue.

Panic reactions to perceived security threats do not help the situation. While undeniably terrorists, criminals and economic migrants exist and may try to enter New Zealand by improper means, this should not be used to undermine the rights of refugees. Most refugees are not criminals, nor suspected of being so. We should not punish refugees in order to appear to be taking action about other less worthy candidates.

Nevertheless, despite these growing fears about boat people and terrorists, New Zealand is getting closer to finding the appropriate balance between the right of refugees not to be detained, as set out in Article 31(2) of the Convention, and the right of the state to control its borders. 
